\title{
PELATIHAN PENGELOLAAN KEUANGAN BADAN KESWADAYAAN MASYARAKAT (BKM) DI KELURAHAN LIPU KOTA BAUBAU SULAWESI TENGGARA
}

\author{
Rudi Abdullah ${ }^{(1)}$ Dan Asrianti Dja'wa ${ }^{(2)}$ \\ ${ }^{1}$ Department Of Management, Faculty of Economic, Universitas Muhammadiyah Buton. Jl. \\ Betoambari No 36 Kota Baubau, 93712, Indonesia \\ ${ }^{2}$ Department of Development Economic, Faculty of Economic and Business, Universitas Halu \\ Oleo. Kampus Baru Andonohu No 36 Kota Kendari, 93561, Indonesia

\section{E-mail : $\underline{\text { rudiabdullah@umbuton.ac.id }}$}

\begin{abstract}
Abstrak. Pentingnya perencanaan keuangan dan keterampilan mengenai pengelolaan keuangan bagi para anggota BKM sangat diperlukan karena kondisi masih banyaknya anggota BKM yang belum sepenuhnya memahami terkait kebijakan dan alur pengelolaan keuangan BKM dan Kinerja keuangan sekretariat BKM masih rendah. Tujuan penelitian ini adalah : 1) Untuk meningkatkan pemahaman tentang kebijakan manajemen keuangan dan alur pengelolaan keuangan, dan 2) Untuk meningkatkan kinerja keuangan Sekretariat BKM. Metode penelitian ini adalah: 1) Pelatihan Intensif, 2) Diskusi, dan 3) Pertanyaan dan Jawaban. Hasil dari penelitian ini menunjukkan bahwa peserta PKM telah memahami tentang kebijakan, aliran, dan prosedur manajemen keuangan yang berdampak pada kinerja BKM. Sekretariat BKM dalam manajemen keuangan terdiri dari: Kebijakan Pembukaan Rekening Bank, Pengeluaran Pendanaan Kebijakan, Kas Kebijakan, Sistem Pembukuan Kebijakan, dan Pembuatan Kebijakan RAPB BKM. Selanjutnya, aliran Pembukuan BKM dimulai dari pencatatan transaksi pada masing-masing bukti berdasarkan jenis transaksi, kemudian bukti diposting pada setiap buku sesuai dengan jenis transaksi yang telah ditulis di bukti. Setelah aliran selesai dilaporkan Penghasilakan dan Pengeluaran, dan Rencana dan Pernyataan Realisasi. Sekretariat BKM memperoleh laporan keuangan bulanan, yang menjelaskan secara rinci perubahan keuangan dalam satu bulan periode dan laporan tahunan.
\end{abstract}

Kata kunci: Pelatihan, Manajemen Keuangan, Laporan Penghasilan dan Pengeluaran, dan Rencana dan Realisasi 


\section{BAB I \\ PENDAHULUAN}

\subsection{Analisis Situasi}

Upaya pemerintah dalam mengurangi tingkat kemiskinan di Indonesia adalah salah satunya melalui pemberdayaan masyarakat. Lembaga pemerintah yang menangani masalah pemberdayaan masyarakat adalah Badan Keswadayaan Masyarakat (BKM). Menurut Suyono (2006), BKM pada prinsipnya adalah wadah sinergis masyarakat bagi orang-orang yang peduli terhadap permasalahan kemiskinan di komunitasnya. Pelaksanaan misi pemberdayaan, BKM menumbuhkembangkan kelompok-kelompok swadaya masyarakat sebagai media belajar masyarakat untuk memecahkan masalah kemiskinan secara mandiri. Fungsi BKM sebagai wadah sinergi berbagai upaya penanggulangan kemiskinan dan pemberdayaan masyarakat. Badan ini memfasilitasi kebutuhan dari kelompok-kelompok swadaya masyarakat (KSM) yang ada atau masyarakat miskin pada umumnya untuk dapat terus tumbuh, berkembang jaringan usahanya dan meningkatkan perekonomiannya.

Peraturan Presiden Republik Indonesia Nomor 13 Tahun 2009 tentang Koordinasi Penanggulangan Kemiskinan pada Pasal 1 tertulis bahwa "Penanggulangan kemiskinan adalah kebijakan dan program pemerintah dan pemerintah daerah yang dilakukan secara sistematis, terencana dan bersinergi dengan dunia usaha dan masyarakat untuk mengurangi jumlah penduduk miskin dalam rangka meningkatkan derajat kesejahteraan rakyat". Program yang terbentuk dari undang-undang ini adalah Program Penanggulangan Kemiskinan di Perkotaan (P2KP). Program ini pertama kali dilaksanakan sejak Tahun 1999. Tahun 2008, secara penuh P2KP berubah menjadi Program Nasional Pemberdayaan Masyarakat Mandiri (PNPM Mandiri). Saat ini, PNPM Mandiri berubah nama kembali menjadi Program Kota Tanpa Kumuh (KOTAKU) sejak Tahun 2016. Program KOTAKU dalam proses pengucuran dananya dibantu oleh Badan Keswadayaan 
Masyarakat atau Lembaga

Keswadayaan

Masyarakat

(BKM/LKM).

$$
\text { Kelurahan Lipu }
$$

merupakan salah satu dari 43 kelurahan yang ada di Kota Baubau yang menjadi sasaran dari Program Kota Tanpa Kumuh (KOTAKU) dan satu dari empat kelurahan target penanganan permukiman kumuh kelurahan Kota Baubau 2016-2019. Adapun Badan Keswadayaan Masyarakat "POMAASI" merupakan BKM yang ada di Kelurahan Lipu Kota Baubau dan memiliki peran membantu pengelolaan Bantuan Dana Infrastruktur (BDI) KOTAKU terhadap Kelurahan Palabusa berdasarkan SK Walikota Baubau Nomor 653/309/VIII/2015 tentang Penetapan Lokasi Perumahan Kumuh dan Permukiman Kumuh Dalam Wilayah Kota Baubau.

Hasil pendataan Tim Inti Perencanaan Partisipatif BKM POMAASI Kel. Lipu menjelaskan bahwa penduduk Kelurahan Lipu secara umum merupakan penduduk dengan tingkat penghasilan yang berada dibawah rata-rata. Kondisi masyarakat secara umum bekerja pada sektor kelautan baik itu sebagai nelayan, petani rumput laut, dan sebagainya. Berikut ini kondisi masyarakat Kel. Lipu pada Tabel 1:

Tabel 1. Jumlah Penduduk MBR dan Non MBR Kel. Lipu

\begin{tabular}{|c|l|c|c|c|c|}
\hline NO & Alamat RT/RW & $\begin{array}{c}\text { Jumlah Kepala } \\
\text { Rumah Tangga }\end{array}$ & $\begin{array}{c}\text { Jumlah Kepala } \\
\text { Keluarga }\end{array}$ & $\begin{array}{c}\text { Jumlah Kepala } \\
\text { Rumah Tangga MBR }\end{array}$ & $\begin{array}{c}\text { Jumlah Kepala Rumah } \\
\text { Tangga Non MBR }\end{array}$ \\
\hline 1 & RT001-RW003 & 36 & 45 & 35 & 1 \\
\hline 2 & RT001-RW001 & 56 & 64 & 56 & 0 \\
\hline 3 & RT001-RW002 & 47 & 52 & 46 & 1 \\
\hline 4 & RT002-RW003 & 34 & 45 & 33 & 1 \\
\hline 5 & RT002-RW001 & 23 & 38 & 9 & 14 \\
\hline 6 & RT002-RW002 & 38 & 44 & 37 & 1 \\
\hline 7 & RT003-RW003 & 49 & 54 & 44 & 5 \\
\hline 8 & RT003-RW001 & 34 & 46 & 31 & 3 \\
\hline 9 & RT003-RW002 & 41 & 41 & 37 & 4 \\
\hline 10 & RT004-RW002 & 44 & 46 & 43 & 1 \\
\hline \multicolumn{2}{|l}{ Jumlah } & 402 & 475 & 371 & 31 \\
\hline
\end{tabular}

Sumber : Baseline 100-0-100 Tahun 2018

Tabel 1 menjelaskan bahwa hampir lebih dari 90\% penduduk Kelurahan Lipu merupakan masyarakat berpenghasilan rendah. Penduduk Kelurahan Lipu berdasarkan jenis mata pencahariannya terbagi beberapa jenis diantaranya:

Tabel 2 . Jumlah Penduduk Berdasarkan Mata Pencaharian Kel. Lipu

\begin{tabular}{|c|l|c|}
\hline $\begin{array}{c}\text { N } \\
\text { o }\end{array}$ & \multicolumn{1}{|c|}{$\begin{array}{c}\text { Mata } \\
\text { Pencaharian }\end{array}$} & $\begin{array}{c}\text { Jumlah } \\
\text { Penduduk }\end{array}$ \\
\hline 1 & $\begin{array}{l}\text { Pertanian,Perkebu } \\
\text { nan, Kehutanan, } \\
\text { Peternakan }\end{array}$ & 183 \\
\hline 2 & Perikanan/Nelaya & 102 \\
\hline
\end{tabular}




\begin{tabular}{|c|l|c|} 
& $\mathrm{n}$ & \\
\hline 3 & $\begin{array}{l}\text { Pertambangan/Ga } \\
\text { lian }\end{array}$ & 8 \\
\hline 4 & Industri/Pabrik & 8 \\
\hline 5 & $\begin{array}{l}\text { Konstruksi/Bangu } \\
\text { nan }\end{array}$ & 2 \\
\hline 6 & Perdagangan/Jasa & 89 \\
\hline 7 & $\begin{array}{l}\text { Pegawai } \\
\text { Pemerintah }\end{array}$ & 10 \\
\hline \multicolumn{2}{|c|}{ JUMLAH } & $\mathbf{4 0 2}$ \\
\hline
\end{tabular}

Sumber: Baseline 100-0-100 Tahun 2018

Penduduk Kelurahan

Lipu sebesar 38\% memenuhi kebutuhan sehari hari dengan bekerja di sektor Pertanian, Perkebunan, Kehutanan, Peternakan, sektor Perikanan/Nelayan sebesar $30 \%$ dan sektor perdagangan sebesar $23 \%$. Selebihnya bervariasi mulai dari industri, galian, ataupun pegawai pemerintah.

Kedua informasi diatas menggambarkan masyarakat Kelurahan Lipu identik dengan masyarakat Pertanian, Perkebunan, Kehutanan, Peternakan dengan pendidikan dan kesejahteraan yang relatif rendah. Hal tersebut disebabkan kondisi geografis dan latar belakang pendidikan yang dimiliki oleh masyarakat setempat. Kondisi ini pula yang menjadikan Kelurahan Lipu menjadi salah satu kawasan kumuh priotritas II yang cukup mendapat perhatian dari berbagai pihak, baik Pemda maupun swasta. Salah satunya adalah Bantuan Dana Infrastruktur (BDI) yang wajib dikelola oleh Kelurahan Palabusa melalui bantuan BKM setempat untuk meminimalkan skala kawasan kumuh. Berdasarkan analisis kondisi di atas, kami memiliki program kegiatan pelatihan pengelolaan keuangan bagi para anggota BKM POMAASI di Kelurahan Lipu.

\subsection{Identifikasi Dan Rumusan Masalah}

$$
\text { Pentingnya perencanaan }
$$

keuangan dan keterampilan mengenai pengelolaan keuangan bagi para anggota BKM sangat diperlukan karena kondisi sebagai berikut:

1. Masih banyaknya anggota BKM yang belum sepenuhnya memahami terkait kebijakan dan alur pengelolaan keuangan BKM.

2. Kinerja keuangan sekretariat BKM masih rendah.

Berdasarkan identifikasi masalah tersebut, maka dapat Ekonomi, Sosial, dan Budaya 1496 
dirumuskan permasalahan sebagai berikut:

a. Bagaimana cara meningkatkan pemahaman terkait kebijakan dan alur pengelolaan keuangan BKM?

b. Bagaimana cara meningkatkan kinerja keuangan sekretariat BKM?

\subsection{Tujuan Pkm}

Kegiatan pengabdian berupa pelatihan ini memiliki tujuan sebagai berikut:

a. Meningkatkan pemahaman terkait kebijakan dan alur pengelolaan keuangan BKM.

b. Meningkatkan kinerja keuangan sekretariat BKM.

\subsection{Manfaat PKM}

Setelah memperoleh kegiatan pelatihan ini, para peserta pelatihan akan mendapat kebermanfaatan baik secara teoritis maupun praktik. Para peserta pelatihan juga diharapkan dapat menambah wawasan dan pemahaman tentang pengelolaan keuangan. Adapun manfaat kegiatan pelatihan ini adalah: a. Peserta memiliki pemahaman terkait kebijakan dan alur pengelolaan keuangan BKM.

b. Peserta mampu meningkatkan kinerja keuangan sekretariat BKM.

\section{BAB II \\ METODE KEGIATAN PKM}

\subsection{Khalayak Sasaran Kegiatan PKM}

Khalayak sasaran kegiatan pengabdian pada masyarakat ini adalah anggota Badan Keswadayaan Masyarakat (BKM) Pomaasi Kelurahan Lipu yang berjumlah 35 orang.

\subsection{Metode Kegiatan PKM}

Metode yang digunakan dalam kegiatan ini meliputi:

a. Pelatihan intensif

Kegiatan pelatihan dilaksanakan dalam beberapa hari secara intensif. Bentuknya di ruangan, dengan menggunakan panduan materi yang telah dikembangkan.

b. Diskusi

$\begin{array}{llr}\text { Berisi } & \text { kegiatan } & \text { diskusi } \\ \text { tentang } & \text { topik-topik } & \text { yang }\end{array}$


dapat diangkat dalam

pelatihan perencanaan keuangan dan keterampilan mengenai pengelolaan keuangan.

c. Tanya Jawab

Berisi kegiatan tanya jawab tentang permasalahan atau kendala dalam pelatihan perencanaan keuangan dan keterampilan mengenai pengelolaan keuangan

d. Penugasan

Berisi kegiatan pemberian tugas kepada peserta pelatihan untuk rincian pengelolaan keuangan.

$$
\text { Sebagai narasumber }
$$

kegiatan ini adalah dosen Tim Pengabdian PKM UM Buton, yaitu: Rudi Abdullah, S.E., M.M., Ak., dan Asrianti Dja'wa, SE., M.Ec.Dev. Adapun materi pelatihan yang di paparkan adalah tentang kebijakan pengelolaan keuangan BKM, kebijakan pengelolaan keuangan KSM dan pengawasan keuangan BKM serta memberikan soal latihan terkait pengelolaan keuangan.

\subsection{Langkah-Langkah Kegiatan PKM}

Proses pencapaian dalam melaksanakan misi pemberdayaan,
BKM menumbuhkembangkan kelompok-kelompok swadaya masyarakat sebagai media belajar masyarakat untuk memecahkan masalah kemiskinan secara mandiri. Adapun diagram alur dari PKM ini adalah sebagai berikut:

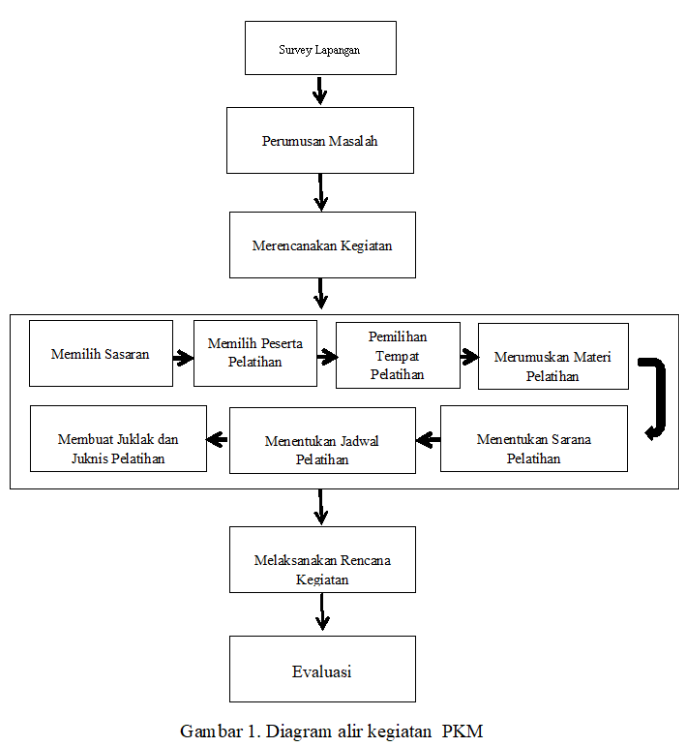

Dari analisis situasi dan survey di lapangan didapatkan permasalahan yaitu masih banyaknya anggota BKM yang belum sepenuhnya memahami terkait kebijakan dan alur pengelolaan keuangan BKM, Kinerja keuangan sekretariat BKM masih rendah dan anggota BKM belum memiliki keterampilan yang memadai dalam pengelolaan keuangan. Strategi yang dilakukan untuk mengatasi permasalahan tersebut adalah dengan 
pelatihan pengelolaan keuangan bagi anggota BKM. Adapun langkah kegiatan tersebut dapat diukur keberhasilannya dengan instrumen angket untuk memastikan tercapainya tujuan PKM kepada peserta kegiatan.

Tabel 1. Tujuan dan Indikator PKM

\begin{tabular}{|c|l|l|c|}
\hline $\begin{array}{c}\text { N } \\
\text { O }\end{array}$ & TUJUA & $\begin{array}{l}\text { INDIKAT } \\
\text { OR }\end{array}$ & $\begin{array}{c}\text { INSTRU } \\
\text { MEN }\end{array}$ \\
\hline & $\begin{array}{l}\text { Meningk } \\
\text { atkan } \\
\text { pemaham } \\
\text { an terkait } \\
\text { kebijakan } \\
\text { dan alur } \\
\text { pengelola } \\
\text { an }\end{array}$ & $\begin{array}{l}\text { Mengetahu } \\
\text { kebijakan } \\
\text { dan alur } \\
\text { pengelolaa } \\
\text { n keuangan }\end{array}$ & \\
\\
$\begin{array}{l}\text { keuangan } \\
\text { BKM }\end{array}$ & AnM & \\
\hline & $\begin{array}{l}\text { Meningk } \\
\text { atkan }\end{array}$ & $\begin{array}{l}\text { Memaksim } \\
\text { alkan }\end{array}$ & \\
kinerja & $\begin{array}{l}\text { kinerja } \\
\text { keuangan }\end{array}$ & Angket \\
& $\begin{array}{l}\text { keuangan } \\
\text { sekretaria } \\
\text { t BKM. }\end{array}$ & $\begin{array}{l}\text { sekretariat } \\
\text { BKM. }\end{array}$ & \\
\hline
\end{tabular}

\subsection{Faktor Pendukung Dan Penghambat}

Faktor pendukung dari kegiatan

PKM ini adalah:

a. Kerjasama dengan Lembaga

Penelitian dan Pengabdian

Kepada Masyarakat (LPPM)

Universitas Muhammadiyah

Buton, Fakultas Ekonomi dan

Fakultas Hukum. b. Kerjasama dengan Dirjen Cipta Karya Program KOTAKU OSP 8 Wilayah Sulawesi Tenggara dalam penyelenggaraan dan peserta. Kerjasama ini memudahkan Tim Pengabdi PKM dari UM Buton untuk dapat fokus dalam penyampaian materi kegiatan.

c. Dukungan dari Pihak Pemerintah Setempat (Lurah Lipu) dan tokoh masyarakat dalam kegiatan PKM tersebut dengan memberikan materi terkait kondisi terkini Pengelolaan BKM POMAASI Kelurahan Lipu serta segala hal yang dibutuhkan dalam upaya persiapan pelatihan pengelolaan keuangan.

Faktor penghambat dari kegiatan ini hampir tidak ada sehingga kegiatan PKM dapat berjalan dengan lancar. Waktu yang terbatas untuk lebih banyak mengeksplorasi tentang kebijakan dan alur pengeloaan keuangan diatasi dengan bimbingan intensif antara Tim Pengabdi PKM UM Buton dengan anggota BKM. Hasil Ekonomi, Sosial, dan Budaya 
pelatihan berupa keterampilan dalam menyusun laporan keuangan BKM.

\section{BAB III}

PELAKSANAAN KEGIATAN PKM

\subsection{HASIL PELAKSANAAN}

\section{KEGIATAN PKM}

1. Evaluasi Proses Kegiatan PKM

a. Evaluasi Kepuasan Peserta

PKM

Salah satu indikator

keberhasilan kegiatan PKM ditunjukan

dalam

pelaksanaan kegiatan PKM.

Hal tersebut juga tercermin dari angket yang diberikan kepada peserta kegiatan PKM seperti pada Gambar 2.

Gambar 2. Respon Peserta PKM

Gambar

tersebut mendeskripsikan bahwa presentase peserta PKM pada kategori sangat puas sebesar 50\%, kategori puas

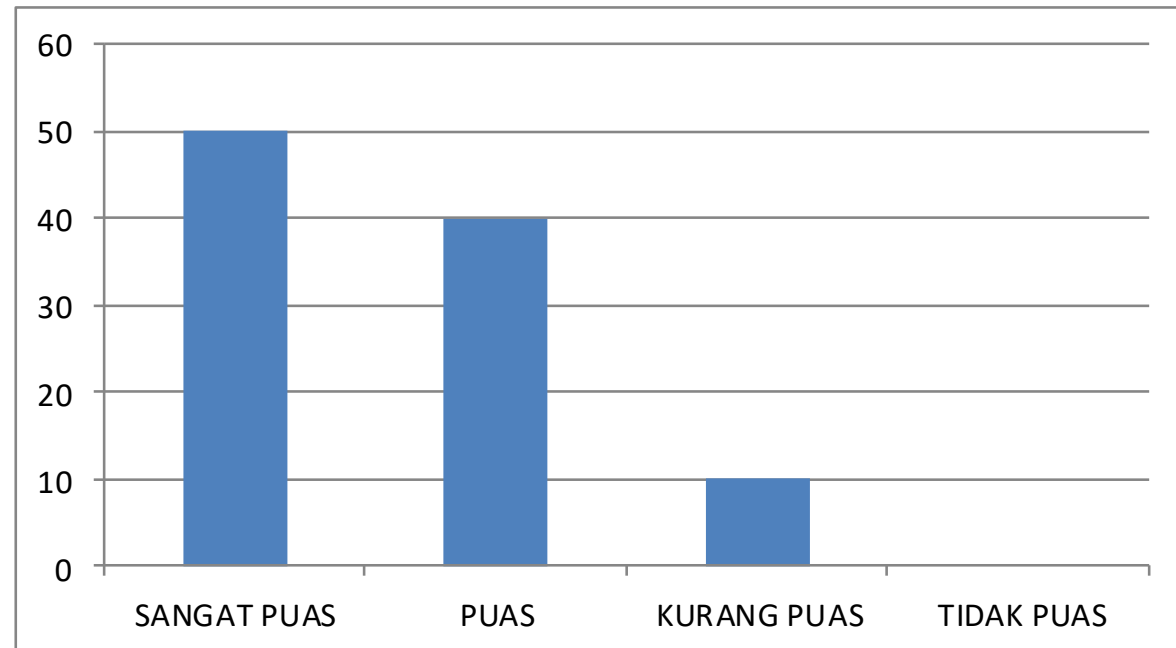

adalah adanya respon positif dari peserta kegiatan. Jika respon yang ditunjukkan peserta pada kategori positif atau puas maka dapat diartikan bahwa kegiatan tersebut memberikan kesan yang baik bagi peserta. Antusiasme peserta selama mengikuti kegiatan sebesar 40\%, kategori kurang puas sebesar $10 \%$ dan kategori tidak puas sebesar 0\%. Hasil tersebut menunjukkan peserta PKM memberikan respon yang positif terhadap kegiatan PKM yang telah dilakukan.

\begin{tabular}{l|l} 
Ekonomi, Sosial, dan Budaya & 1500
\end{tabular} 
b. Evaluasi Kesesuaian

Kegiatan PKM dengan

Kebutuhan Masyarakat

Indikator keberhasilan

kegiatan PKM lainnya juga

dapat dilihat dari evaluasi

kesesuaian kegiatan PKM

dengan kebutuhan

masyarakat sasaran. Harapan

Tim PKM UM.BUTON

adalah materi pelatihan yang

diberikan dapat memecahkan

masalah yang ada, seperti

kesulitan

dalam

meningkatkan pemahaman

terkait kebijakan dan alur

pengelolaan keuangan BKM,

cara meningkatkan kinerja

keuangan sekretariat BKM

dan cara meningkatkan

keterampilan dalam

pengelolaan keuangan bagi

anggota BKM. Berikut ini

hasil dari angket peserta

kegiatan PKM yang mengeksplorasi apakah pelatihan yang diberikan sesuai dengan kebutuhan masyarakat setempat.

Gambar 3. Respon

Kesesuaian Kebutuhan

Gambar tersebut

mendeskripsikan bahwa peserta PKM menyatakan materi pelatihan PKM yang diberikan sangat sesuai dengan kebutuhan masyarakat yang menjadi peserta pelatihan. Peserta pelatihan menjadi lebih paham terkait kebijakan dan alur pengelolaan keuangan BKM, cara meningkatkan kinerja keuangan sekretariat BKM dan cara meningkatkan keterampilan dalam pengelolaan keuangan bagi anggota BKM.

c. Evaluasi Kerjasama Program

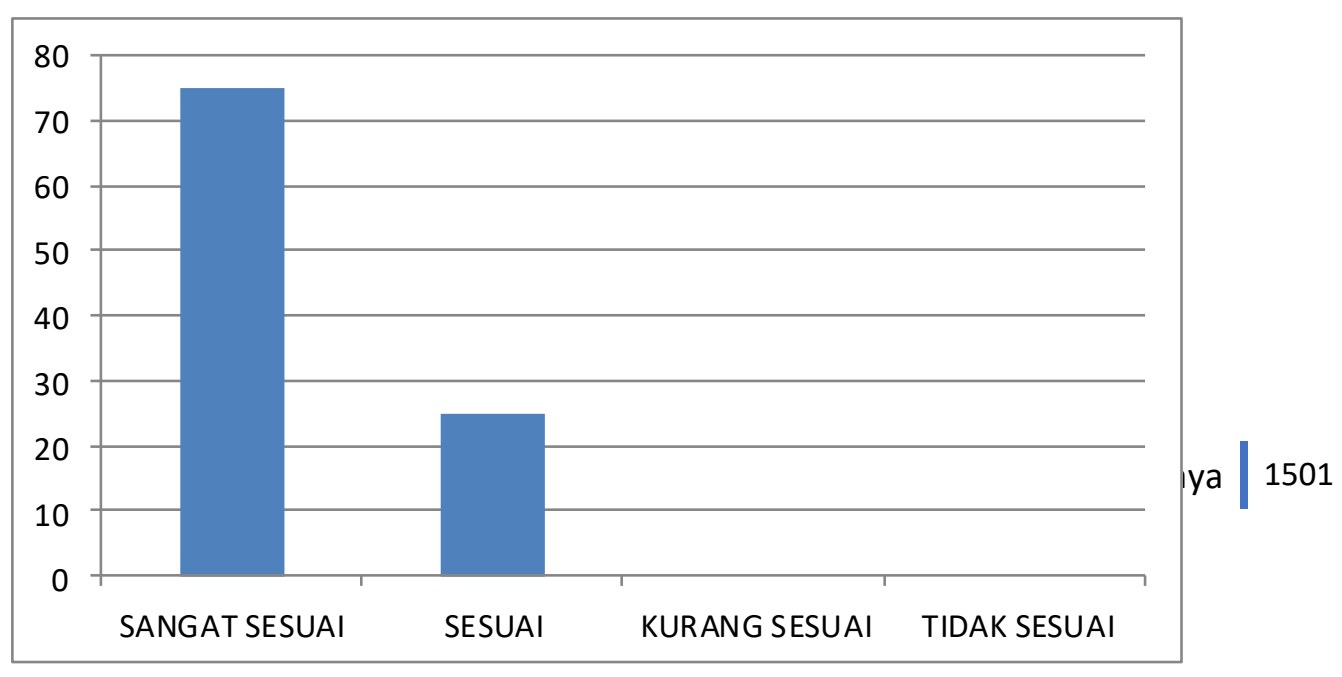


Kemitraan Masyarakat

(PKM)

Kerjasama Tim PKM

UM.BUTON dengan mitra

atau peserta kegiatan juga

tidak luput dari penilaian.

Kesan yang ditangkap oleh

mitra dapat dilihat dari hasil

angket yang dibagikan

kepada peserta PKM.

Gambar 4. Respon Peserta

PKM
Gambar tersebut mendeskripsikan bahwa peserta PKM memberikan penilaian terkait kerjasama Tim PKM UM.BUTON dengan peserta kegiatan sebagian besar pada kategori baik dan sangat baik.

\section{Evaluasi Produk}

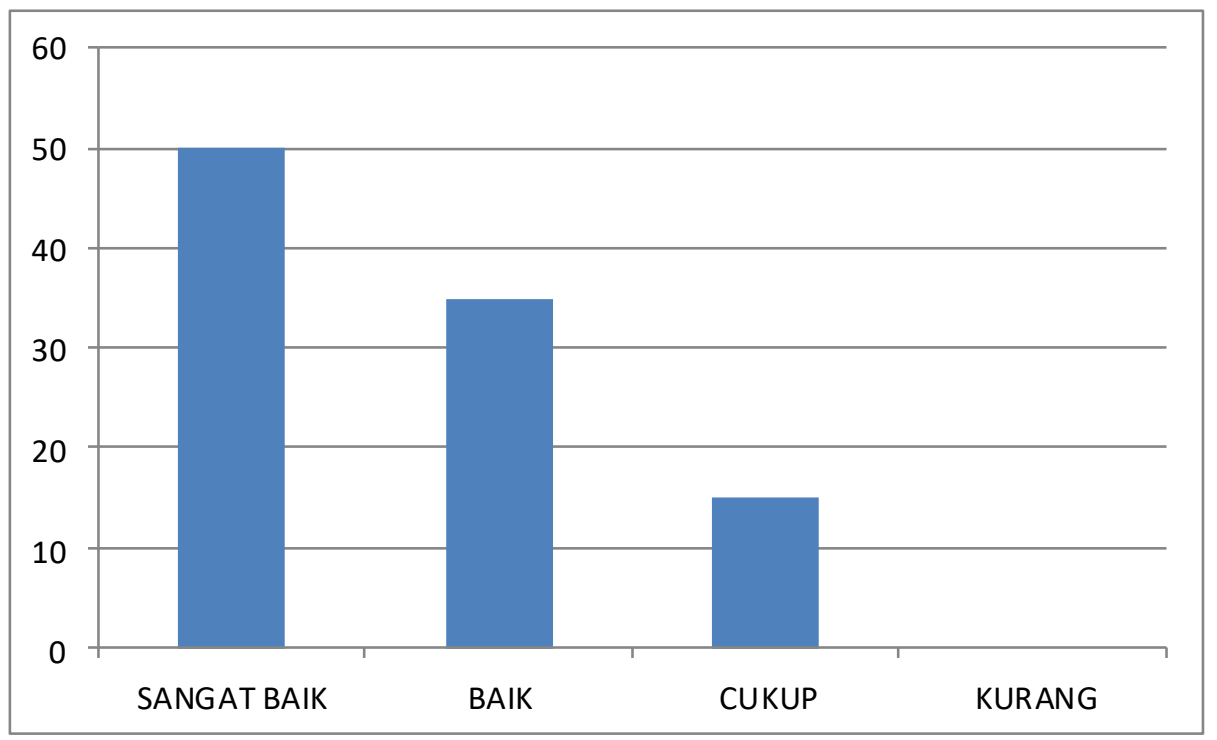


a. Pengetahuan

Kebijakan

Dan

Pengelolaan Keuangan BKM tentang

peningkatan

pemahaman terkait kebijakan

dan alur pengelolaan

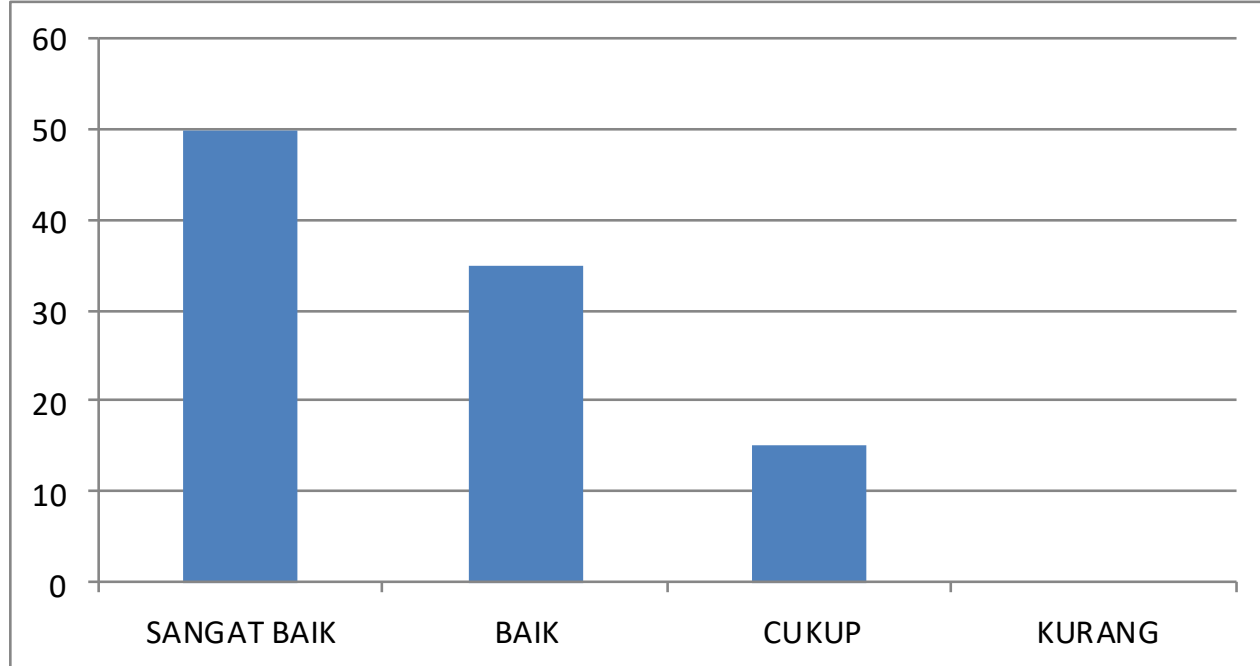

Pengetahuan peserta

keuangan BKM bukanlah

kegiatan tentang kebijakan

persoalan yang sulit, tetapi

dan alur pengelolaan membutuhkan komitmen dari

keuangan BKM sebelum

pelatihan dilaksanakan setiap perangkat BKM untuk bersama merintis dan adalah sangat minim. Selama mengembangkan pemahaman ini mereka belum memiliki terkait kebijakan dan alur pengalaman termasuk tidak pengelolaan keuangan BKM. memiliki pengetahuan yang Dari angket yang disebarkan cukup tentang kebijakan dan kepada peserta kegiatan PKM alur pengelolaan keuangan. Pelatihan ini menitikberatkan diperoleh hasil seperti pada Gambar 5.

pada arti penting pengelolan keuangan, tujuan Gambar 5. Pemahaman Terkait pengelolaan keuangan dan Kebijakan Dan Alur Pengelolaan pengawasan keuangan pada Keuangan BKM

BKM. Selain itu, disampaikan pula materi 


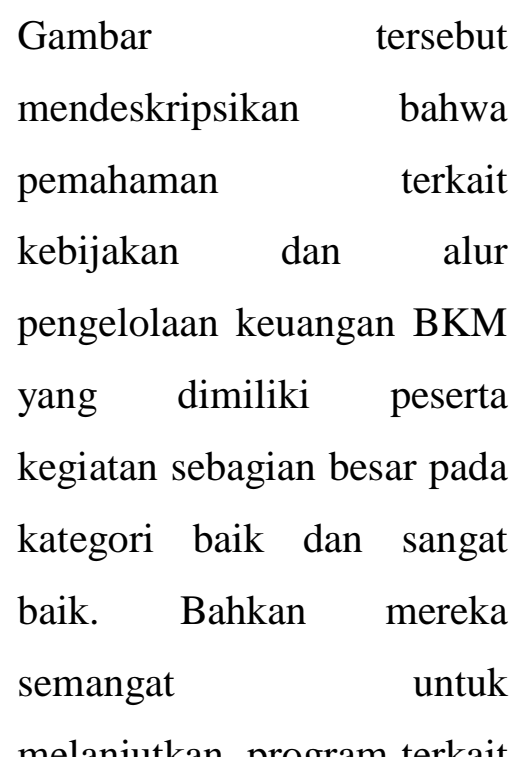

melanjutkan program terkait kebijakan dan alur pengelolaan keuangan BKM.

b. Evaluasi Produk Berupa Meningkatkan Kinerja

Keuangan Sekretariat BKM

Hasil dari pelatihan ini adalah meningkatkan kinerja keuangan sekretariat BKM. Telah dibuatkan draft pembukuan sekretariat BKM baik pembukuan untuk menyusun laporan keuangan maupun pembukuan terkait alokasi dana lingkungan dan sosial. Bukti pembukuan BKM terlampir.

\subsection{Pembahasan Hasil Pelaksanaan Kegiatan PKM}

Peserta kegiatan PKM

telah memahami kebijakan, alur dan prosedur pengelolaan keuangan sehingga berdampak pada memadainya kinerja sekretariat BKM. Deskripsi dari masing-masing hasil pelaksanaan kegiatan pelatihan pengelolaan keuangan BKM adalah sebagai berikut:

1. Kebijakan Pengelolaan Keuangan BKM

a. Kebijakan Pembukaan Rekening Bank

Setiap BKM wajib memiliki rekening bank dengan mengatasnamakan nama organisasi bukan nama pribadi. Speciment rekening bank BKM harus ditandatangani oleh minimal tiga orang anggota BKM aktif, yakni Koordinator, Sekretaris dan salah seorang anggota BKM. Setiap penarikan dana dari rekening bank harus ditandatangani oleh tiga nama penandatangan yang didasarkan pada hasil rapat anggota BKM dan didukung atau dilampiri Berita Acara 
(BA) hasil rapat. Apabila

BKM hendak melakukan

transfer dana kepada

Kelompok Swadaya

Masyarakat (KSM) sebagai

mitra BKM, maka transfer

bank hanya dilakukan dengan

bukti transaksi yang sudah

ditandatangani oleh BKM

dan disertai Berita Acara

persetujuan pemanfaatan

dana. Penarikan atau transfer

dana lebih dari Rp5.000.000,-

harus diketahui oleh

Koordinator BKM.

b. Kebijakan Pengeluaran Dana

Semua pembayaran dengan

Bukti Kas Keluar (BKK)

harus dirangkum per bulan

dan dilakukan inspeksi oleh

Koordinator BKM. BKK

tersebut harus

ditandatangani oleh pihak

yang menerima, pihak yang

menyetujui, dan pihak yang

mencatat.

Semua

pengeluaran BKK dicatat

dalam sistem pembukuan

yang berlaku dan dilakukan

uji silang dengan daftar

pengeluaran (bukti kas keluar), sifat atau jenis pembayarannya harus teridentifikasi secara jelas. Semua lembar copy BKK harus disimpan sesuai dengan aturan penyimpanan (diodner dan urut tanggal transaksi). BKK harus jelas dan rinci penggunaannya, diperlukan bukti/nota toko sebagai lampiran BKK jika pengeluaran/pembelanjaan ke Toko. Blanko BKK yang masih kosong tidak diperkenankan

ditandatangani oleh pihak yang menerima, pihak yang menyetujui, dan pihak yang mencatat.

c. Kebijakan Kas

Jumlah kas ditangan tidak lebih dari Rp.1.500.000,dengan kurun waktu maksimal 2 hari kerja. Pengelola kas adalah sekretaris (berdasarkan peran dan fungsi Sekretaris BKM dalam struktur organisasi). Semua transaksi kas wajib didukung dengan Bukti Kas Keluar (BKK), 
Bukti Kas Masuk (BKM)

atau Bukti Pemindah

Bukuan (BPB). Sekretaris

BKM wajib melakukan kas

opname secara berkala, minimal 1 bulan sekali.

d. Kebijakan

Sistem

Pembukuan

Sistem pembukuan yang

digunakan adalah sistem

pembukuan berpasangan

(double entry) dengan

perpaduan antara cash basis

dan accrual basis.

Pembukuan berpasangan

merupakan cara pencatatan

yang lebih memungkinkan

untuk mencatat penerimaan

dan pengeluaran dengan

mencatat di kedua akun

tersebut. Sistem ini

memudahkan untuk

melakukan pengecekan

seberapa besar perbedaannya

jika dibandingkan dengan

anggarannya masing-masing.

Pembukuan dijilid per buku

per tahun

e. Kebijakan Penyusunan

RAPB BKM
Anggaran tahunan BKM

disusun berdasarkan rencana

tahunan BKM yang sesuai dengan prioritas kegiatan.

Selain itu, BKM harus menyusun rencana anggaran biaya operasional. Setiap tahun akuntansi, BKM dibantu oleh Sekretaris dan Unit Pengelola (UP) baik Unit Pengelola Keuangan (UPK), Unit Pengelola Lingkungan (UPL) maupun Unit Pengelola Sosial (UPS) harus menyusun anggaran yang tepat dan realistik dalam menaksir penerimaan dan pengeluaran lembaga dan disampaikan pada Rembug Warga Tahunan (RWT).

Alur pembukuan BKM dapat diuraikan pada diagram alir berikut ini: 


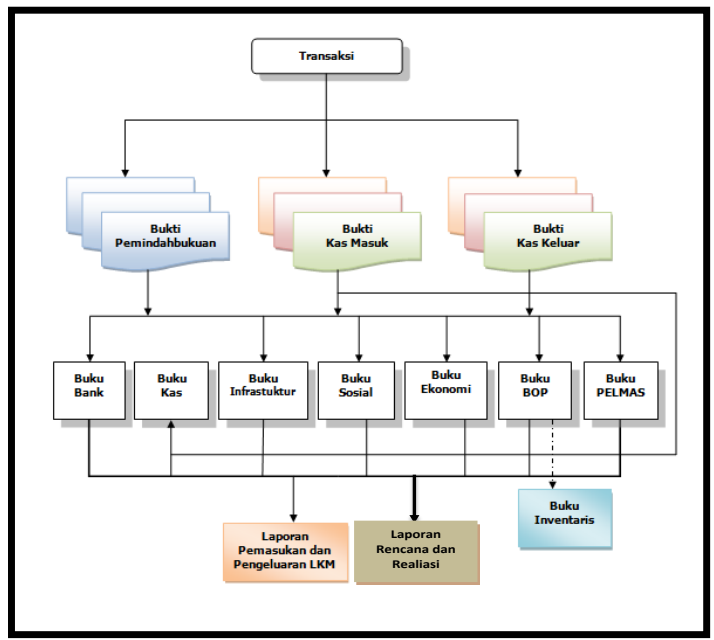

2. Kinerja Keuangan Sekretariat BKM

Sekretariat BKM harus menghasilkan laporan pengelolaan keuangan bulanan bagi BKM, yang menjelaskan secara rinci perubahan keuangan dalam satu periode bulanan dan laporan tahunan. Pemantauan oleh BKM dengan melihat Saldo buku kas periode berjalan harus tepat sesuai dengan jumlah tunai dalam kotak kas kecil. Saldo ini harus dicek dengan melakukan penghitungan uang tunai pada akhir bulan dengan mengisi Form Kas Opname. Setiap perbedaan yang terjadi harus dijelaskan, dan selanjutnya dilakukan penyesuaian. Elemen yang sangat penting dalam pelaporan keuangan adalah pengauditan. Selain pemeriksaan eksternal yang harus dilakukan oleh auditor independen setiap tahun, BKM hendaknya memiliki sistem pemeriksaan internal yang setidaknya telah dilakukan secara rutin.

\section{BAB IV \\ PENUTUP}

\subsection{Kesimpulan}

1. Peserta kegiatan PKM telah memahami kebijakan, alur dan prosedur pengelolaan keuangan sehingga berdampak pada memadainya kinerja sekretariat BKM. Adapun kebijakan pengelolaan keuangan BKM terdiri dari: Kebijakan Pembukaan Rekening Bank, Kebijakan Pengeluaran Dana, Kebijakan Kas, Kebijakan Sistem Pembukuan, dan Kebijakan Penyusunan RAPB BKM. Selanjutnya, alur pembukuan BKM dimulai dari pencatatan transaksi pada masing-masing bukti sesuai dengan jenis transasksinya \begin{tabular}{l|l} 
Ekonomi, Sosial, dan Budaya & 1507
\end{tabular} 
(BKM, BKK, BPB), kemudian bukti-bukti tersebut diposting pada masing-masing BUKU sesuai dengan jenis transaksi yang tercatat dalam bukti tersebut, dan dilaporkan pada Laporan Pemasukan dan Pengeluaran BKM/LKM, serta Laporan Rencana dan Realisasi.

3. Sekretariat BKM harus menghasilkan laporan pengelolaan keuangan bulanan bagi BKM, yang menjelaskan secara rinci perubahan keuangan dalam satu periode bulanan dan laporan tahunan.

\subsection{Saran}

1. Kegiatan PKM ini perlu dilanjutkan dengan pendampingan intensif. Hal ini sangat dibutuhkan karena keberadaan BKM yang menjadi sasaran pelaksana kerja dari mitra BKM, maka kebutuhan mitra selanjutnya adalah bagaimana kinerja BKM tersebut dalam mengelola keuangan secara efektif dan efisien.

2. Pendampingan intensif dari tim PKM UM Buton perlu terus dilakukan sehingga jalinan kemitraan kampus dengan masyarakat dapat tumbuh dan berkembang serta saling menguntungkan.

\section{DAFTAR PUSTAKA}

Dirjen Cipta Karya Program KOTAKU OSP 8 Sultra. 2017. Modul Pelatihan Masyarakat dalam Pengelolaan Keuangan.

Peraturan Presiden Republik Indonesia Nomor 13 Tahun 2009 tentang Koordinasi Penanggulangan Kemiskinan.

SK Walikota Baubau Nomor 653/309/VIII/2015 tentang Penetapan Lokasi Perumahan Kumuh dan Permukiman Kumuh Dalam Wilayah Kota Baubau.

Suyono, Haryono. 2006. Pemberdayaan Masyarakat: Mengatur Manusia Mandiri, Demokratis, dan Berbudaya. Jakarta:LP3ES. 